\title{
ZALETY I WADY WPROWADZENIA SYSTEMU OCHRONY W SEKTORZE BANKÓW SPÓŁDZIELCZYCH W POLSCE
}

\section{WSTĘP}

Począwszy od 2008 r. bankowość spółdzielcza przeżywa w zachodniej części Unii Europejskiej swój wielki renesans. Główną tego przyczyną są liczne skandale związane z komercyjnymi instytucjami finansowymi, które w konsekwencji spowodowały powstanie globalnego kryzysu finansowego ${ }^{1}$. W literaturze zagranicznej panuje pogląd, że negatywne doświadczenia bankowości komercyjnej powoduja, iż banki spółdzielcze jawią się jako instytucje charakteryzujące się dalece posuniętą ostrożnością i unikające inwestowania w ryzykowne aktywa ${ }^{2}$. W Polsce w okresie kryzysu wystapiły co prawda nieliczne problemy również i w bankach spółdzielczych, ale jak dowiodły badania, także nasze banki spółdzielcze na tle bankowości komercyjnej w najgorszym kryzysowym momencie były ostoją ostrożności. Istotne jest zatem, zwłaszcza dla banków spółdzielczych, utrzymanie i dalsze wzmacnianie ich bezpieczeństwa za pomoca różnego typu systemów ochrony. W ostatnich latach ważną rolę dla rodzimych banków spółdzielczych odgrywa szczególnie International Protection Scheme (IPS).

Celem niniejszego artykułu jest usystematyzowanie poglądów na temat zalet i wad systemu ochrony w sektorze banków spółdzielczych w Polsce rozpatrywanych $\mathrm{z}$ różnych punktów widzenia, przed jego wdrożeniem i w jego trakcie. Problemem badawczym jest aspekt zasadności wdrożenia systemu ochrony w sektorze banków spółdzielczych w Polsce rozpatrywany z punktu widzenia potrzeb banków spółdzielczych. Uczestnikami systemu ochrony mogą być również banki zrzeszające, ze względu jednak na ich liczbę (tylko dwa) i wyjątkowy profil (łączą one funkcje banku zrzeszającego i komercyjnego) wyłączono je z rozważań niniejszego tekstu. Autorka stawia w związku z tym następująca hipotezę badawczą: przystępowanie banków spółdzielczych do IPS w Polsce ze względu na przewagę zalet nad wadami jest korzystne z punktu widzenia marketingowego i finansowego samych banków. Zakres czasowy badań obejmuje okres od 2012 do marca 2017 r. Jest to więc czas, w którym toczyła się dyskusja

${ }^{1}$ A. Deville, E. Lamarque, Diversity of Cooperative Bank Governance Models Questioning by Regulation: An International Qualitative Research, Working Paper 2015-1, Paris 2015.

${ }^{2}$ F. R. Chaddad, M. L. Cook, Understanding new cooperative models: an ownership-control rights typology, „Review of Agricultural Economics” 26, 2004, s. 348-360. 
na temat zasadności samego wdrożenia modelu IPS w Polsce (lata 2012-2015) oraz jego ostatecznego kształtu. Wdrożenie rozumie się przy tym jako okres tworzenia odpowiedniego otoczenia prawnego, a następnie powstawanie i rozpoczynanie działalności przez konkretne podmioty działające zgodnie z przyjętymi regulacjami prawnymi. W okresie tym pojawiły się również pierwsze wnioski oceniające wdrożony w Polsce (13 września 2015 r.) model systemu ochrony, jak również powstały dwie grupy - systemy ochrony. Sa to Spółdzielczy System Ochrony SGB zawiązany 23 listopada 2015 r. oraz System Ochrony Zrzeszenia BPS zawiązany 31 grudnia $2015 \mathrm{r}$.

W artykule przedstawiono istotę i cel funkcjonowania IPS, wskazano genezę jego powstania oraz podstawy prawne wdrożenia. Następnie dokonano szczegółowego przeglądu zalet i wad tego systemu. Ich ocena obejmuje poglądy dotyczace IPS zawarte w literaturze, a także komentarze wynikające z doświadczeń praktyków. Ostatnia część artykułu zawiera ocenę zalet i wad wprowadzonego modelu IPS w polskich bankach spółdzielczych. W artykule zastosowano metodę obserwacyjną (w rozumieniu Jerzego Apanowicza ${ }^{3}$ ), analizę i krytykę piśmiennictwa. Przeprowadzone zostały również wywiady ukierunkowane w wybranych bankach spółdzielczych.

\section{ISTOTA I CEL FUNKCJONOWANIA IPS}

Definicja IPS dostępna w literaturze zagranicznej opiera się na określeniu celu jego tworzenia, którym to celem jest ochrona finansowa swoich członków przed niewypłacalnością i zapewnienie stałości aktywów ${ }^{4}$. Definicja ta bazuje wprost na zapisach regulacji rozporządzenia Capital Requirements Regulation $(\mathrm{CRR})^{5}$. Podobnego sposobu definiowania używa się w polskich periodykach, gdzie wskazuje się, iz IPS to system, którego celem jest ochrona stabilności banków spółdzielczych i zrzeszających przez bieżący monitoring ryzyka działalności oraz zapobieganie trudnym sytuacjom; ma on też na celu wzmacniać kapitałowo całe zrzeszenie oraz jego uczestników, co będzie zapewnione poprzez spełnienie (na poziomie grupy) norm płynnościowych stawianych przez rozporządzenie CRR i dyrektywę CRD IV ${ }^{6}$ (Capital Requirements Directive IV Parlamentu Europejskiego) ${ }^{7}$. W istocie jest to zabieg formalny polegajacy na

${ }^{3}$ J. Apanowicz, Metodologia ogólna, Bernardinum, Gdynia 2002, s. 62-63.

${ }^{4}$ M. Blume, Dellinger, Bankwesengesetz - BWG Kommentar, Wien 2007.

${ }^{5}$ Rozporządzenie Parlamentu Europejskiego i Rady (UE) nr 575/2013 z 26 czerwca 2013 r. w sprawie wymogów ostrożnościowych dla instytucji kredytowych i firm inwestycyjnych, zmieniające rozporządzenie (UE) $\mathrm{nr}$ 648/2012 (Capital Requirements Regulation, CRR).

${ }^{6}$ Dyrektywa Parlamentu Europejskiego i Rady 2013/36/UE z 26 czerwca 2013 r. w sprawie warunków dopuszczenia instytucji kredytowych do działalności oraz nadzoru ostrożnościowego nad instytucjami kredytowymi i firmami inwestycyjnymi, zmieniająca dyrektywę 2002/87/WE i uchylająca dyrektywy 2006/48/WE oraz 2006/49/WE (Capital Requirements Directive IV, CRD IV).

${ }^{7}$ M. Groszek, M. Radzikowski, Bezpośrednie i pośrednie obciażenia polskich banków AD 2015. Próba inwentaryzacji i pomiaru niektórych z nich, „Zeszyty mBank-CASE” 2015, nr 138. 
liczeniu wszystkich funduszy uczestników IPS dla oceny ryzyka. Natomiast nie zwiększa się wcale bufor kapitałowy w grupie banków spółdzielczych.

Dla pełnego obrazu podkreślić należy, że w literaturze można spotkać się także z definicja, zgodnie z którą model IPS polega na tym, że pojedyncza agencja, zwykle istniejący wcześniej ubezpieczyciel depozytów bankowych, dodatkowo świadczy usługi polegające na zabezpieczeniu inwestorów i/lub uposażonych z polis ubezpieczeniowych ${ }^{8}$. Tak rozumiany IPS nie jest jednak przedmiotem zainteresowania niniejszego artykułu.

\section{GENEZA IPS}

Sama idea tworzenia systemu ochrony nie jest na świecie koncepcją nowa. Przykładem rozwijającego się IPS-u, nieinicjowanego przez narzucone odgórnie przepisy prawa, jest niemieckie BVR (Stowarzyszenie Banków Niemieckich). Funkcjonuje ono już od niemal 70 lat $^{9}$, a gromadzenie środków trwa nawet od lat trzydziestych ubiegłego wieku. Co ważniejsze, oddolnie wypracowane rozwiązanie BVR jest modelem, który sprawdził się w Niemczech w praktyce: poprawił z jednej strony poziom bezpieczeństwa banków, a z drugiej - pozwolił zachować autonomię działania uczestników. System BVR obejmuje 1021 banków spółdzielczych (typu Volksbank i Reiffaisen) oraz 2 instytucje centralne (DZ Bank i WGZ Bank) ${ }^{10}$. W samych Niemczech istnieje również podobna struktura IPS, lecz obejmująca 413 banki oszczędnościowe (Spaarkasse) i 7 banków krajowych (Landesbank) ${ }^{11}$. Podobnie zorganizowany jest również system IPS w Austrii, gdzie funkcjonują 3 niezależne sieci:

- Erste Group obejmująca 47 banków oszczędnościowych z Erste Bankiem jako instytucją zarządzajaccą IPS,

- RZB Group obejmująca 474 lokalnych banków typu Reiffeisen, 8 banków regionalnych i Reiffeizen Zentral Bank jako instytucję zarządzająca;

- Osterreichische Volksbanken AG obejmująca 26 regionalnych banków ludowych (typu Volksbank) i 1 bank zrzeszający (VBW), a zarządzana przez OGV.

\footnotetext{
${ }^{8}$ Por. Integrated Protection Schemes. Research Paper, International Association of Deposit Insurers, Bank For International Settlements, III 2015; B. Beat, W. Susanna, Design, Structure and Implementation of a Modern Deposit Insurance Scheme, SUERF Studies: 2009/5, Vienna 2009; Oxera Consulting, Description and Assessment of the National Investor Compensation Schemes Established in Accordance with Directive 97/9/EC, Consultation Paper for European Commission, January 2005; Oxera Consulting, Insurance Guarantee Schemes in the EU, Consultation Paper for European Commission, November 2007; S. Schich, K. Byoung-Hwan, Guarantee Arrangements for Financial Promises: How Widely Should the Safety Net Be Cast?, Financial Market Trends, OECD 2011.

${ }^{9}$ R. Szewczyk, IPS-innowacyjne rozwiqzanie gwarantujace bezpieczeństwo i rozwój, „Bank Spółdzielczy” 2015, nr 6(583).

${ }^{10}$ Dane według stanu na 31 grudnia 2015 r., za: C. Choulet, Institutional protection systems: are they banking groups?, Eco Conjucture Economic Research, January 2017.

${ }^{11}$ Dane według stanu na 31 grudnia 2015 r., za: C. Choulet, op. cit.
} 
Również w innych krajach europejskich można spotkać się z systemami ochrony, lecz obejmujacymi zdecydowanie mniej banków niż w przypadku Niemiec czy Austrii. Przykładowo w Hiszpanii funkcjonują dwa systemy ochrony:

- Grupo Cooperativo Cajamar z 19 kasami oszczędnościowymi i bankami spółdzielczymi (Cajas) i jedną instytucją dominującą (Banco de Crédito Social Cooperativo SA);

- Grupo Cooperativo Solventia z 6 kasami rolnymi (Cajas Rural) i jedna instytucją dominująca (Caja Rural de Almendralejo).

Sa też kraje europejskie, w których „samopomoc” banków w zakresie zachowania głównie odpowiedniego poziomu płynności finansowej opiera się nie na systemie ochrony, lecz na banku zrzeszajacym jako organie centralnym (zgodnie z art. 10 CRR). Sa to na przykład ${ }^{12}$ :

- Francja, w której funkcję organu centralnego pełnia Credit Agricole (grupa obejmuje 2476 banków lokalnych, 9 banków regionalnych i Credit Agricole SA), BPCE (grupa obejmuje 18 banków popularnych, 17 kas oszczędnościowych i BPCE SA) oraz Credit Mutuel (2124 banków spółdzielczych, 18 banków regionalnych i $\mathrm{CNCM}$ );

- Holandia, w której 106 lokalnych banków spółdzielczych (typu Rabobank) zrzesza Rabobank Nederland;

- Finlandia, gdzie OP Financial Group obejmuje 180 banków spółdzielczych i OP Cooperative jako bank zrzeszający.

Kluczowe różnice pomiędzy systemami IPS a systemami zarządzanymi przez organ centralny (zgodnie z art. $10 \mathrm{CRR}$ ) dotyczą:

- podmiotu pełniącego rolę zarządcy - może to być odrębna jednostka utworzona tylko w tym celu (w systemie IPS) lub bank prowadzący również swoją własną działalność (w trybie art. $10 \mathrm{CRR}$ );

- profilu biznesowego jednostek wchodzących w skład grupy - homogeniczne (w systemie IPS) lub z nieograniczonym zakresem (w trybie art. 10 CRR);

- rachunkowego (bilansowego) traktowania podmiotów wchodzących w skład grupy - niebędacymi (w systemie IPS) lub będacymi (w trybie art. 10 CRR) podmiotami powiązanymi w myśl regulacji rachunkowych.

Zarówno na świecie ${ }^{13}$, jak i w Polsce ${ }^{14}$ wskazuje się, że dążenie do upowszechnienia IPS za pomoca unijnych rozwiazań prawnych (CRD IV/CRR ${ }^{15}$ ), jest próbą odwrócenia występującego od kilku lat kryzysu sektora banków komercyjnych, wynikajacego z tzw. hazardu moralnego, jak i różnego rodzaju zaniedbań związanych z zarządzaniem ryzykiem. W szczególności dotyczy to

12 Ibidem.

${ }^{13}$ Por. T. Stern, Regulating liquidity risks within “institutional protection schemes”, „Beijing Law Review" 5, 2014, s. 210-239; J. Berrospide, Bank liquidity hoarding and the financial crisis: an empirical evaluation, „Finance and Economics Discussion Series” no. 2013-03, Divisions of Research \& Statistics and Monetary Affairs. Federal Reserve Board, Washington, D.C., 2013.

14 Por. M. Oleszko, w: System ochrony Instytucjonalnej IPS, potraktujmy to jako szansę, „Bank Wspólnych Sił, Magazyn Grupy BPS, 2012, nr 3; M. Groszek, M. Radzikowski, Bezpośrednie i pośrednie obciażenia polskich banków AD 2015. Próba inwentaryzacji i pomiaru niektórych z nich, „Zeszyty mBank-CASE” 2015, nr 138.

15 Szczegółowe informacje nt. CRDIV/CRR w następnym punkcie artykułu. 
zarządzania ryzykiem płynności ${ }^{16}$, która w literaturze światowej nazywana jest nawet „życiodajną krwią instytucji finansowych” ${ }^{17}$ bądź „smarem do kół systemu finansowego, tak że funkcjonują one bez tarcia"18.

Znaczenie płynności jako kluczowego aspektu dla instytucji finansowych podkreśla się również w literaturze polskiej ${ }^{19}$. Obok jednak wspomnianych problemów z ryzykiem płynności ${ }^{20}$ czy aktywami, wskazuje się także, że obecnie problemem są również zmagania z problemami z pasywami banków ${ }^{21}$, w czym również mogą pomóc wspomniane wyżej rozwiązania prawne, których skutkiem jest wdrożenie systemu ochrony. Uprzednie regulacje, choć były ważne i pomocne $\mathrm{e}^{22}$, to jednak zorientowane były jedynie na duże banki ${ }^{23}$, z pominięciem problemów specyficznych dla banków spółdzielczych ${ }^{24}$.

\section{PODSTAWY PRAWNE FUNKCJONOWANIA IPS}

Warto zwrócić uwagę na fakt, że na świecie w bankowości spółdzielczej istnieją generalnie cztery stopnie integracji ${ }^{25}$ : od podstawowej grupy spółdzielczej, przez zdecentralizowaną grupę spółdzielcza, skonsolidowaną grupę banków spółdzielczych posiadającą IPS, działającą zgodnie z CRR (art. 113 ust. 7), do najbardziej zintegrowanej - skonsolidowanej grupy banków spółdzielczych, która funkcjonuje na podstawie art. 10 lub art. 113 ust. 6 CRR.

Podstawa prawną wdrożenia IPS jest więc rozporządzenie CRR (dla banków spółdzielczych art. 113 i 411-428 rozporządzenia CRR) oraz pakiet CRD IV. Najważniejsze zmiany w związku z wejściem ich w życie dotyczą składników

${ }^{16}$ K. Nikolaou, Liquidity (Risk) Concepts-Definitions and Interactions, ECB Working Paper 2009.

17 E. S. Harris, Ben Bernanke's Fed: The Federal Reserve after Greenspan, Harvard Business Press, Boston 2013.

${ }_{18}$ K. Nikolaou, op. cit.

19 M. Oleszko, op. cit.

20 Por. A. Bervas, Market liquidity and its corporation into risk management, „Banque de France, Financial Stability Review" 2009, no. 8; M. Affinito, Central Bank Refinancing, Interbank Markets and the Hypothesis of Liquidity Hoarding: Evidence from a Euro-Area Banking System, ECB Working Paper Series 2013; O. Aspachs, E. Nier, M. Tiesset, Liquidity, Banking Regulation and the Macroeconomy. Evidence on Bank Liquidity, ww.bis.org/bcbs/events/ rtf05AspachsNierTiesset.pdf [dostęp: 8.03.2017]; C. Deléchat et al., The Determinants of Banks' Liquidity Buffers in Central America, IMF Working Paper, WP/12/301, International Monetary Fund, 2012.

${ }^{21}$ I. Distinguin, C. Roulet, A. Tarazi, Bank regulatory capital buffer and liquidity: evidence from U.S. and European publicly traded banks, „Journal of Banking \& Finance” 2013.

${ }^{22}$ J. Larson, The Basel Accords, University of Iowa College of Law Center for International Finance and Development, Iowa City 2011; R. A. Nowak, How Effective Is Global Financial Regulation? The Basel Accords' Role in Mitigating Banking Crises, Duke University, Durham 2011; A. Blundell-Wignall, P. Atkinson, Thinking beyond Basel III: necessary solutions for capital and liquidity, „OECD Journal: Financial Market Trends” 2010.

23 M. Oleszko, op. cit.

${ }^{24}$ Diagnoza stanu przed wprowadzeniem IPS w Polsce ze względu na inne ukierunkowanie artykułu przedstawiona zostaje jedynie hasłowo.

${ }_{25}$ H. Groeneveld, Governance of European Cooperative Banks: Overview, Issues and Recommendations, Working Paper of Tilburg University, September 2015. 
kapitału założycielskiego, funduszu udziałowego i norm płynności. Mimo więc tego, że pierwsze podmioty spełniające funkcje IPS funkcjonowały w niektórych krajach od 70 lat, należy stwierdzić, że ich rola i znaczenie wzrosły dopiero po przyjęciu przez Parlament Europejski i Radę pakietu CRD IV, zgodnie z którym banki należące do IPS zyskały dodatkowe przywileje regulacyjne ${ }^{26}$.

\section{WPROWADZENIE IPS W SEKTORZE BANKÓW SPÓŁDZIELCZYCH W POLSCE}

Na podstawie analizy debat dotyczacych wzorców i modeli rozpatrywanych w pracach nad koncepcją IPS w Polsce można stwierdzić, że jego kształt jest wypadkową trzech głównych wzorców w zakresie sposobu przystępowania do systemu (fakultatywny/ obligatoryjny), traktowania go przez nadzór bankowy (jako jedna grupę/ jako wiele niezależnych podmiotów), czy jego rozpoznania na gruncie prawa bilansowego (jako podmioty niezależne / jako podmioty powiązane). Ich znaczenie obrazuje schemat 1.

\section{Schemat 1}

Czynniki wpływające na kształt systemu ochrony funkcjonującego w Polsce

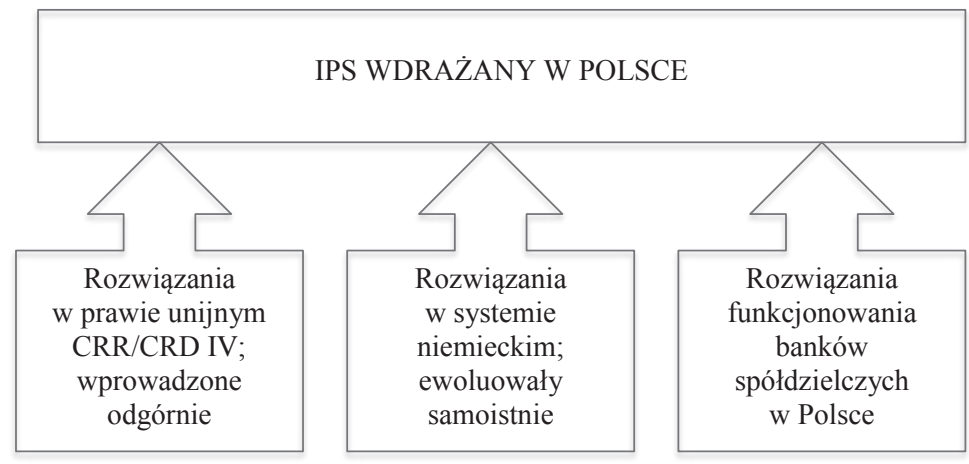

Źródło: opracowanie własne.

Jak wynika ze schematu 1, podstawą wdrażania IPS w Polsce była realizacja przepisów unijnych. Najważniejsze zmiany związane z wejściem w życie wspomnianego pakietu CRR/CRD IV dotyczą składników kwestii kapitału założycielskiego, funduszu udziałowego i norm płynności ${ }^{27}$.

Odwołujac się zaś do doświadczeń niemieckich, należy wskazać, iż już w 2012 r. pojawiły się sugestie, żeby w Polsce (po wykonanej analizie funkcjo-

${ }^{26}$ J. Koleśnik, Institutional Protection Scheme $w$ sektorze banków spótdzielczych $w$ Polsce modelowe rozwiazania, „Annales Universitatis Mariae Curie-Skłodowska” 2013.

${ }^{27}$ Zob. https://www.knf.gov.pl/crd/pakiet_crd4_banki_spoldzielcze.html [dostęp: 8.03.2017]. 
nowania IPS na świecie ${ }^{28}$ ) przyjąć właśnie model znany z BVR ${ }^{29}$. Jak podkreślają osoby odpowiedzialne za tworzenie polskiego systemu ochrony, to właśnie u naszych zachodnich sassiadów podpatrywano rozwiązania i sprawdzano, jak systemy z tak bogata historią funkcjonują w praktyce ${ }^{30}$.

Debata środowiska mającego wpływ na funkcjonowanie banków spółdzielczych w Polsce doprowadziła jednak ostatecznie do konkluzji, że obok niewątpliwych wpływów przepisów prawa unijnego oraz poznania doświadczeń niemieckich, konieczne jest wzięcie pod uwagę także regulacji i rozwiązań polskich w zakresie funkcjonowania i zrzeszania się naszych banków spółdzielczych $^{31}$, czego wyrazem sa przepisy ustawy z 7 grudnia 2000 r. o funkcjonowaniu banków spółdzielczych, ich zrzeszaniu się i bankach zrzeszających (Dz. U. 2016, poz. 1826), w której cały rozdz. 3a: System ochrony, poświęcony jest przedmiotowemu zagadnieniu i stanowi podstawę funkcjonowania systemu ochrony banków spółdzielczych w Polsce. Ważne jest bowiem, aby uregulowania w zakresie IPS były zgodne nie tylko ze ramami wspólnotowymi, lecz także uwzględniały specyfikę krajowej bankowości spółdzielczej.

Konieczna stała się także nowelizacja ustawy o funkcjonowaniu banków spółdzielczych, która miała określić szczegółowe zasady funkcjonowania systemów ochrony ${ }^{32}$. W znowelizowanej ustawie zawarto rozdz. 3a: System ochrony, którego przepisy mają na celu zapewnienie płynności i wypłacalności każdego jego uczestnika na zasadach określonych w ustawie i w umowie systemu ochrony, w szczególności przez udzielanie pożyczek, gwarancji i poręczeń na warunkach określonych w umowie systemu ochrony (art. 22a, ust. 1 ustawy o funkcjonowaniu banków spółdzielczych). Zgodnie z art. 22i przywołanej ustawy, zadaniami systemu ochrony, którym zgodnie z polskimi regulacjami może zarządzać bank zrzeszający lub specjalnie w tym celu utworzona jednostka zarządzająca, mogąca działać w formie spółki akcyjnej lub spółdzielni osób prawnych) jest głównie:

- reprezentowanie systemu ochrony na zasadach określonych w umowie systemu ochrony;

- zarzadzanie systemem ochrony na zasadach określonych w umowie systemu ochrony;

- podejmowanie działań koniecznych do zapewnienia bezpieczeństwa depozytów gromadzonych u uczestników systemu ochrony i zgodności ich działalności z postanowieniami umowy systemu ochrony.

Opis prac nad wprowadzaniem zmian został zawarty m.in. w Raporcie o sytuacji ekonomicznej banków z 2016 r. ${ }^{33}$ Wskazano w nim, że po wielu la-

${ }^{28}$ R. Kałużny, Ocena $i$ analiza sytuacji majatkowo-finansowej, w: A. Gospodarowicz, A. Nosowski (red.), Zarzadzanie instytucjami kredytowymi, C. H. Beck, Warszawa 2016.

${ }^{29}$ Czyli model niemiecki. Twierdzi tak przykładowo Wojciech Kulak, w: System Ochrony Instytucjonalnej IPS, potraktujmy to jako szanse 2012 (dalej jako: System ochrony instytucjonalnej IPS).

${ }^{30}$ R. Szewczyk, op. cit.

31 J. Koleśnik, op. cit.

${ }^{32}$ M. Groszek, M. Radzikowski, op. cit.

${ }^{33}$ Związek Banków Polskich, „Raport o sytuacji ekonomicznej banków”, Warszawski Instytut Bankowości 2016, nr 6. 
tach udało się wypracować rozwiązanie ${ }^{34}$ nie tylko takie, które pozwala wprowadzić pakiet CRD IV/CRR, lecz przede wszystkim umożliwiające zmniejszenie obciążeń regulacyjnych banków spółdzielczych z tytułu wymogów kapitałowych i płynności, a także obniżenie partycypacji członków IPS w tworzeniu funduszy Bankowego Funduszu Gwarancyjnego (BFG).

Funkcjonujący obecnie polski model IPS w bankowości spółdzielczej zaprezentowany został na schemacie 2 .

\section{Schemat 2}

Model IPS funkcjonujący w Polsce

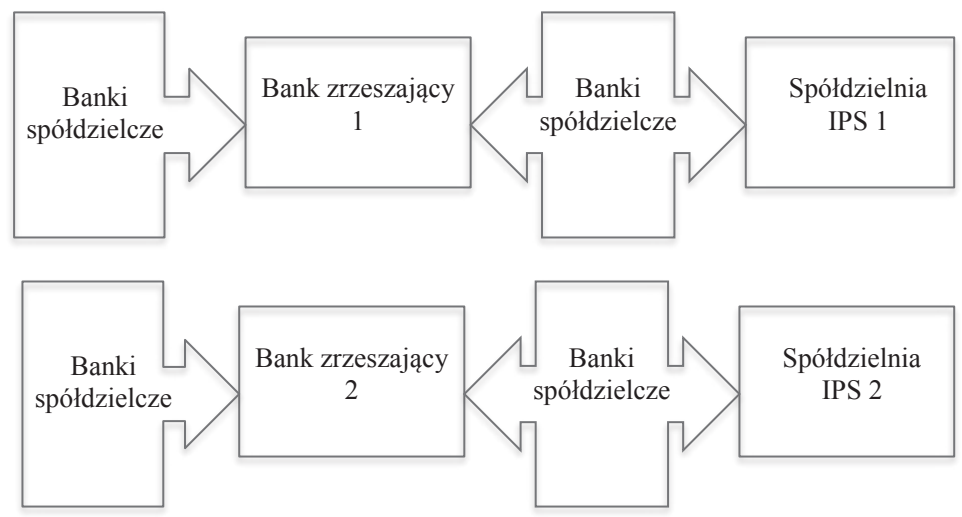

Źródło: opracowanie własne.

Jak wynika ze schematu 2, ostatecznie powołane zostały (w końcu 2015 r.) dwa systemy IPS (systemy ochrony w rozumieniu rozdz. 3a ustawy o funkcjonowaniu banków spółdzielczych) funkcjonujące przy istniejących zrzeszeniach banków spółdzielczych. Jak wskazano podczas debaty 20 czerwca 2016 r..$^{35}$, niespełna rok od uchwalenia podstaw prawnych do tworzenia systemów ochrony instytucjonalnej należała do nich już większość polskich banków spółdzielczych. W rzeczywistości z 354 instytucji zrzeszonych w Banku Polskiej Spółdzielczości (BPS) 255 było już członkami IPS, z 7 trwały negocjacje, kilkanaście kolejnych banków złożyło zgłoszenie do systemu. W SGB - Banku (SGB) na 202 zrzeszone banki 7 nie należało do IPS, 2 złożyły już aplikację. Przyjęty model IPS jest więc już, obok BFG, elementem systemu banków spółdzielczych i zrzeszających ${ }^{36}$. Jest on buforem i stabilizatorem, ponieważ stanowi dodatkową ochronę dzięki monitorowaniu oraz prewencji w zakresie ryzyka każdego z członków systemu. Działalność IPS

${ }^{34}$ Chodzi tu o rozwiązanie przyjęte w ustawie o zmianie ustawy o funkcjonowaniu banków spółdzielczych, ich zrzeszaniu się i bankach zrzeszających, która została uchwalona 25 czerwca 2015 r.

35 J. Ochocki, relacja z debaty: „Banki spółdzielcze: IPS - i co dalej?”, z udziałem m.in. A. Skowrońskiego, Z. Kupczyka ALEBANK.PL 14.08.2016, s. 16.

${ }^{36}$ M. Groszek, M. Radzikowski, op. cit. 
częściowo uzupełnia, a częściowo pokrywa się z kompetencjami BFG - wspólne jest to, że w obu przypadkach tworzone sa fundusze pomocowe (w BFG fundusz gwarancyjny, a w IPS fundusz zabezpieczający), choć ich przeznaczenie nie musi być takie samo, ponieważ cele tworzenia tychże funduszy sa inne.

Różne zaś jest to, że IPS ma zapewnić także bezpieczne zarządzanie płynnością w gronie zrzeszonych banków oraz optymalne zarządzanie kapitałem, czego nie ma w kompetencjach $\mathrm{BFG}^{37}$. IPS wypełnia więc pewna lukę, ponieważ ma być systemem wczesnego reagowania na ryzyko, zanim potrzebna będzie pomoc BFG. Podkreślić jednak należy, że pomocy BFG we wcześniejszej formie już nie będzie, a ponadto kryteria wsparcia banku ze środków BFG uniemożliwiają udzielenie jej bankowi spółdzielczemu ze względu na problem funkcji krytycznych i kryterium interesu publicznego (por. przykładowo art. 2 pkt 17, art. 66 pkt 2 czy art. 101 ust. 7 pkt 3 ustawy o Bankowym Funduszu Gwarancyjnym, systemie gwarantowania depozytów oraz przymusowej restrukturyzacji).

Warto podkreślić, że wypracowanie polskiego modelu IPS poprzedzone zostało długotrwałym, złożonym i trudnym zarówno merytorycznie, jak i instytucjonalnie procesem konsultacyjnym banków zrzeszających z bankami spółdzielczymi, a także innych platform, jak np. Krajowy Związek Banków Spółdzielczych i Związek Banków Polskich. Przy czym istotne jest, że Umowę Systemu Ochrony zawiera się odrębnie od Umowy Zrzeszenia, natomiast zarządzanie Systemem Ochrony zostało powierzone powołanym w tym celu dwóm spółdzielniom ${ }^{38}$. Taka formuła ma pozytywne znacznie dla skuteczności funkcjonowania IPS, jest to bowiem swego rodzaju model samokontroli sektora - system ochrony z jednej strony nie jest zewnętrzną placówką nadzorcza, tylko spółdzielnia, której członkami są poszczególne banki, jednak równocześnie jest instytucją odrębną od banku zrzeszającego, co ułatwia sprawowanie funkcji nadzorczej bez obaw o uleganie naciskom. Sama formuła tworzenia jednostek zarządzających w ramach bankowości spółdzielczej nie jest jednak całkowicie wolna od wad wynikających ze specyficznych stosunków własnościowych pomiędzy spółdzielniami nadzorowanymi (bankami) a nadzorującymi (IPS, związki rewizyjne).

\section{ZALETY I WADY WPROWADZENIA IPS W POLSCE W ŚWIETLE LITERATURY}

W opracowaniach teoretycznych analizy zalet i wad systemu IPS przedstawiano już kilka lat przed jego wdrożeniem w Polsce. Można zauważyć, iż te z nich, które prezentowano przed ustaleniem ostatecznego kształtu systemu

${ }^{37} \mathrm{Za}$ to BFG może w określonych sytuacjach przeprowadzać przymusową restrukturyzację, do czego to uprawnień nie ma IPS.

${ }^{38}$ Sprawozdanie Zarządu z działalności Banku Polskiej Spółdzielczości Spółka Akcyjna za 2015 r., Warszawa, 23 maja 2016. 
(tabela 1), różnią się od tych, które opisywano po 2015 r., kiedy to już znany był ostateczny kształt polskiego IPS (tabela 2). Różnica ta dotyczy szczególnie zakresu opisywanych wad systemu, co wynika z faktu, że wiele z zarzutów formułowanych pod adresem IPS przez środowisko praktyków oraz tych opisanych w literaturze zostało wyeliminowanych przy opracowywaniu ostatecznego kształtu IPS wdrażanego w Polsce.

\section{Tabela 1}

Zalety i wady IPS wskazywane podczas debat prowadzonych przed wdrożeniem systemu w Polsce

\begin{tabular}{|c|c|}
\hline Zalety & Wady \\
\hline $\begin{array}{l}\text { Korzyści dotyczące płynności i współczynnika } \\
\text { adekwatności kapitałowej, waga aktywów wa- } \\
\text { żonych ryzykiem dla należności wzajemnych } \\
\text { wynosi } 0 \% \text {, wyliczenie miar współczynnika } \\
\text { LCR może odbywać się na poziomie skonsoli- } \\
\text { dowanym (całości IPS) }^{a)}\end{array}$ & $\begin{array}{l}\text { W przypadku występowania dużych zależności } \\
\text { między uczestnikami systemu lub gdy jeden } \\
\text { z uczestników jest „dużym graczem” istnieje } \\
\text { ryzyko, że pojedynczy członek może zagrozić } \\
\text { istnieniu całego systemu, zwłaszcza gdy speł- } \\
\text { nia oba te warunki naraz }{ }^{b}\end{array}$ \\
\hline $\begin{array}{l}\text { Ujednolicenie systemów zarządzania ryzy- } \\
\text { kiem, możliwość całościowego przeglądu ry- } \\
\text { zyka poszczególnych uczestników oraz całego } \\
\text { systemu }^{c)}\end{array}$ & $\begin{array}{l}\text { Obawa przed utrata niezależności, koniecz- } \\
\text { ność podporządkowania się regułom systemu } \\
\text { i dominującej w nim roli banku zrzeszającego }{ }^{d)}\end{array}$ \\
\hline $\begin{array}{l}\text { IPS to genialne narzędzie marketingowe - } \\
\text { banki objęte systemem mają podwójna ochro- } \\
\text { nę (IPS, BFG), przy czym ochrona BFG pozo- } \\
\text { staje na niezmienionym poziomie }{ }^{e}\end{array}$ & $\begin{array}{l}\text { Nadmierne poszukiwanie przyszłych rodzajów } \\
\text { ryzyka kosztem wzrostu dbałości o efektywne } \\
\text { zarządzanie bankiem }{ }^{\text {) }} \\
\text { Obawa fiaska IPS z powodów podobnych jak } \\
\text { w Hiszpaniig }\end{array}$ \\
\hline $\begin{array}{l}\text { Większa integracja przekładająca się, dzięki } \\
\text { działaniu efektu skali, na możliwość zwiększe- } \\
\text { nia udziału w rynku }{ }^{h)}\end{array}$ & $\begin{array}{l}\text { Mnożenie obciążeń finansowych (takich jak } \\
\text { IPS) ograniczajaccych bankom spółdzielczym } \\
\text { możliwość inwestowania i rozwoju }\end{array}$ \\
\hline
\end{tabular}

a) Por. wypowiedź R. Rodek, D. Twardowski, B. Kublik, w: System ochrony instytucjonalnej IPS; ogólniej na ten temat w: J. Koleśnik (op. cit.); a o tym, jak ważne sa to aspekty, wspomina przykładowo W. Kwaśniak (op. cit.), który opisuje problemy z płynnością i kapitałem w bankach spółdzielczych, czy M. Zaleska (op. cit.), opisująca występujące w bankach spółdzielczych problemy z płynnością i wypłacalnością, których rozwiązaniem może być właśnie IPS; ${ }^{b} \mathrm{M}$. Espinosa-Vega, op. cit.; ${ }^{c}$ por. J. Koleśnik, op. cit.; ${ }^{d)}$ ibidem; ${ }^{e)}$ por. System ochrony instytucjonalnej IPS; ${ }^{\text {f) }}$ przytoczona m.in. wypowiedź J. Szperlaka, w: System ochrony instytucjonalnej IPS; g) ibidem - wskazano, że Polska i Hiszpania, w odróżnieniu od działającego od lat trzydziestych XX w. systemu niemieckiego, nie miały kilkudziesięciu lat, żeby zebrać odpowiednie środki gwarantujące bezpieczeństwo; ${ }^{h}$ System ochrony instytucjonalnej IPS; ${ }^{i)}$ M. Groszek, M. Radzikowski, op. cit.

Źródło: opracowanie własne na podstawie M. Espinosa-Vega, op. cit.; System ochrony instytucjonalnej IPS, J. Koleśnik, op. cit.; W. Kwaśniak, op. cit.; M. Zaleska, op. cit., M. Groszek, M. Radzikowski, op. cit. 
Tabela 2

Zalety i wady IPS wskazywane podczas debat prowadzonych po rozpoczęciu wdrażania systemu

\begin{tabular}{|c|c|}
\hline Zalety & Wady \\
\hline $\begin{array}{l}\text { Skuteczna samokontrola - wykrywanie i diagnozowanie za- } \\
\text { grożeń }^{\alpha)}\end{array}$ & \multirow{5}{*}{$\begin{array}{l}\text { System nakłada na banki dale- } \\
\text { ko idace ograniczenia, IPS ogra- } \\
\text { nicza ich autonomię }\end{array}$} \\
\hline $\begin{array}{l}\text { Możliwość uzyskania wsparcia finansowego, stanowiącego } \\
\text { dodatkowy poziom zabezpieczeniac }\end{array}$ & \\
\hline $\begin{array}{l}\text { Zwolnienie banków przynależnych do IPS z części opłat na } \\
\text { rzecz KNF i BFG }{ }^{\text {d) }}\end{array}$ & \\
\hline $\begin{array}{l}\text { Poprawa sytuacji banków pod względem wymogów kapitało- } \\
\text { wych i płynnościowych umocowana w decyzjach } \mathrm{KNF}^{e}\end{array}$ & \\
\hline $\begin{array}{l}\text { Możliwość korzystania z rozwiązań dostępnych instytucjom } \\
\text { funkcjonującym w zintegrowanych grupach }\end{array}$ & \\
\hline
\end{tabular}

a) J. Ochocki, op. cit.; ${ }^{b}$ ibidem; ${ }^{c}$ ibidem, w tym przytoczona wypowiedź P. Szpunara: „system ten stanowi dodatkowy poziom zabezpieczenia placówek bankowych na wypadek kryzysu, ponieważ wsparcie przysługuje w pierwszej kolejności z systemu, dzięki czemu nie jest konieczne ubieganie się o kredyt refinansowany przez NBP”; ${ }^{d)}$ por. m.in. J. Ochocki, op. cit., w tym przytoczona wypowiedź K. Pietraszkiewicza: „te zmiany oznaczają więc wreszcie realizację - tak długo postulowanej przez polskie środowisko bankowe, jak również ekspertów - zasady proporcjonalności, pozwalającej na stosowanie wobec lokalnych instytucji finansowych odpowiednio mniejszych obciążeń aniżeli te, którymi są objęte duże banki komercyjne” oraz Związek Banków Polskich, op. cit., gdzie podkreślono, że przynależność do IPS przełożyła się na zmniejszenie opłat uczestników systemu z tytułu opłaty rocznej i opłaty ostrożnościowej na BFG; ${ }^{e)}$ J. Ochocki, op. cit., w tym przytoczona wypowiedź A. Skowrońskiego: „dostaliśmy od KNF zgodę na stosowanie zerowych wag ryzyka dla ekspozycji między członkami IPS. Dzięki temu całe zrzeszenie uzyskało 1,5 pkt proc. współczynnika wypłacalności [...]. Już niedługo Spółdzielczy System Ochrony SGB zyska również zgodę nadzoru na zagregowane normy płynności pomiędzy poszczególnymi bankami” oraz https://www.knf.gov.pl/crd/pakiet_crd4_banki_spoldzielcze.html [dostęp: 8.03.2017], gdzie wskazuje się, że uczestnicy IPS, mogą stosować 0\% wagę ryzyka kredytowego w odniesieniu do wzajemnych ekspozycji, z wyjątkiem ekspozycji kapitałowych, a grupa spełniająca warunki IPS może wspólnie prezentować miary płynności, wskazano tam także, że dzięki systemowi będzie istniała możliwość zwiększenia limitu zaangażowania kapitałowego wobec podmiotów będących uczestnikami zrzeszenia. Poprawa ta ma jednak charakter statystyczny; f) https://www.knf.gov. pl/crd/pakiet_crd4_banki_spoldzielcze.html [dostęp: 8.03.2017], gdzie wskazano, że dla banków należących do IPS, oprócz udogodnień opisanych w przypisie 47, będzie możliwe także, w razie konieczności, opracowanie wspólnego dla całej grupy planu naprawczego.

Źródło: opracowanie własne na podstawie J. Ochocki, op. cit.; https://www.knf.gov.pl/crd/pakiet_crd4_ banki_spoldzielcze.html oraz https://www.knf.gov.pl/crd/pakiet_crd4_banki_spoldzielcze.html [dostęp: 8.03.2017].

Jak wynika $\mathrm{z}$ zestawienia $\mathrm{w}$ tabelach, aktualne (tj. po rozpoczęciu wdrażania) poglądy prezentowane w literaturze i opiniach praktyków wskazuja na akceptację obecnego kształtu systemu ochrony. Wynika to m.in. z tego, że pewne poważne zarzuty stawiane przed jego wdrożeniem (jak np. mnożenie obciążeń finansowych dla banków spółdzielczych), dziś sa już nieaktualne, choć toczą się wciąż jeszcze pewne spory interpretacyjne (np. w kontekście opłat banków spółdzielczych). 


\section{WNIOSKI Z WDRAŻANIA IPS W POLSCE}

Zalety i wady wdrażania IPS można analizować pod kątem różnych kryteriów - np. z punktu widzenia różnych istotnych podmiotów z otoczenia sektora banków spółdzielczych w Polsce. Zaliczyć do nich można w szczególności:

- banki spółdzielcze i ich zrzeszenie,

- BFG,

- klientów banków spółdzielczych.

Z przystapienia do systemu IPS najwięcej korzyści odniosą banki spółdzielcze. Dzięki niemu poprawi się ich bezpieczeństwo finansowe, ponieważ banki będą miały w razie potrzeby dostęp do środków pomocowych. Będą one miały także lepszą wiedzę o innych członkach IPS, co przełoży się na wzrost wzajemnego zaufania w grupie banków spółdzielczych. To z kolei poprawi relacje wewnątrzzrzeszeniowe. Łatwiej będzie także spełnić normy płynnościowe czy kapitałowe, poprawi się współczynnik kapitałowy zrzeszenia, ponieważ uwolniona zostanie części kapitału, co wynika z faktu, że waga zaangażowania ryzyka pomiędzy poszczególnymi uczestnikami IPS wynosi zero. Banki, uczestnicy systemu ochrony, będą płacić także niższe składki do BFG (choć oczywiście będą ponosić koszty z funkcjonowaniem IPS), a jednocześnie nadal złożone w nich depozyty będą miały ze strony BFG taką samą ochronę, co abstrahując od oczywistej korzyści w zakresie bezpieczeństwa, może być także świetnym narzędziem marketingowym.

Zarządzający bankami spółdzielczymi jako wadę IPS wskazywali z kolei kwestię utraty niezależności. Sugerowali oni także, że decydenci skupiają się na wyszukiwaniu kolejnych rodzajów ryzyka, którymi można (choć nie potrzeba) się zajmować, zamiast przeznaczyć swoje siły i czas na podnoszenie efektywności działania. Do tych opinii pochodzacych z opublikowanych w czasopismach debat warto także dołączyć najświeższe (2017) spostrzeżenia autorki poczynione na podstawie wywiadów prowadzonych w czasie badania sprawozdań finansowych banków spółdzielczych ${ }^{39}$. Z analizy wypowiedzi respondentów wspomnianych badań wynika, że odbiór IPS w wynegocjowanym kształcie, który jest wdrażany w Polsce, jest bardzo pozytywny.

Zarządzający bankami spółdzielczymi wskazują jednak, że ich zdaniem system tak naprawdę wciąż nie jest do końca gotowy, uważaja, że jest on dopiero tworzony, dopracowywany, wdrażany i testowany. Zarządzający bankami spółdzielczymi wskazuja, że chcieliby odczuwać już jakiś pozytywny wpływ tej nowej sytuacji (włączenia do systemu), a takiego wpływu na ten moment praktycznie jeszcze nie ma. Przykładowo bardzo pozytywnie odbierają to, że pewne elementy mają być kontrolowane w ramach IPS, wewnątrz spółdzielni, a nie przez firmy zewnętrze, których bytność zawsze wiąże się z ryzykiem ujawnienia wrażliwych danych. Niestety takich oczekiwanych przez nich audytów czy kontroli na razie nie ma, a nawet jeśli (w jednym z banków) już były, to nadal nie ma żadnej informacji zwrotnej. Zarządzający bankami spółdzielczymi nie sa też zadowoleni z faktu, że nie jest jeszcze do końca ustalony minimalny zakres raportowania, co może stawiać pod znakiem zapytania skuteczność dzia-

${ }^{39}$ Wywiady ukierunkowane przeprowadzono w siedmiu bankach spółdzielczych. 
łania (tzn. obecnie) zintegrowanego systemu monitorowania ryzyka płynności i innych. Zaobserwowanym problemem jest też brak dostępu do niezbędnej wiedzy w postaci rzetelnych interpretacji z zakresu rozwiązań rachunkowych czy podatkowych. Przykładowo, trzy miesiace po dniu bilansowym (w marcu 2017 r.), wiele osób odpowiedzialnych za aspekty rachunkowe i podatkowe w bankach spółdzielczych nadal nie jest zorientowanych, czy składki z tytułu przynależności do IPS są kosztami uzyskania przychodu czy tė̇ nie. Co więcej, podczas szkoleń są im przedstawiane odmienne interpretacje niż te, które wydały organy skarbowe.

Zaletą dla BFG jest z kolei to, że dzięki przystapieniu do IPS, banki spółdzielcze będą mogły stosować wzajemną samokontrolę, co pozwoli ${ }^{40}$ na trzymanie w ryzach i rozwiązywanie wielu problemów na poziomie systemu IPS. Powinno to odciążyć BFG z części zadań.

Jeśli zaś wziaćc pod uwagę wady IPS diagnozowane z punktu widzenia BFG, to choć autorka artykułu nie spotkała się z wypowiedziami jego przedstawicieli na ich temat, to warto tu podkreślić, iż w wyniku wprowadzenia IPS zmniejszeniu uległy opłaty na rzecz BFG, który nadal ustawowo zmuszony jest do gwarantowania depozytów. Trzeba jednak podkreślić, że ochrona IPS powinna wyeliminować, a przynajmniej w znacznym stopniu ograniczyć ryzyko wystapienia sytuacji, gdy pomoc BFG będzie potrzebna, zatem nie można tej kwestii rozpatrywać tak jednostronnie.

Korzyści z przystapienia banków spółdzielczych do IPS uzyskują także ich klienci. Dzięki przystapieniu banków do systemu, zyskują oni podwójną (dwustopniowa) ochronę depozytów zdeponowanych w swoich bankach - uczestnikach systemu IPS ${ }^{41}$. Przy czym, co ważne, ich środki są nadal objęte ochrona ze strony BFG w tym samym zakresie, w jakim były chronione przez BFG przed wprowadzeniem systemu ochrony.

Negatywne aspekty z zakresu wdrażania IPS dla klientów banków spółdzielczych, zdaniem autorki, mogłyby się pojawić, przykładowo w sytuacji, gdyby przynależność do IPS przekładała się na kolejne obciążenia dla banków spółdzielczych i te chciałyby je „przerzucić” na swoich klientów, zwiększając ich opłaty. Tak się jednak nie stało i - zdaniem autorki - banki spółdzielcze nie powinny odczuwać nadmiernych obciążeń, a tym bardziej takich, które uzasadniałyby podwyższanie opłat klientom.

Zalety i wady wdrażania IPS można również syntetycznie pogrupować i oceniać według innego kryterium, tj. przez pryzmat sytuacji, w jakiej znajdują się banki - uczestnicy systemu. Są one bowiem różne dla sytuacji:

- normalnej,

- zagrożenia,

- kryzysowej.

${ }^{40}$ Użyto tu czasu przyszłego, ponieważ, jak wynika ze wspomnianych wywiadów ukierunkowanych, zarządzający bankami spółdzielczymi twierdza, że w praktyce samokontrola jeszcze nie funkcjonuje ze względu na brak pełnego wdrożenia systemu.

${ }^{41}$ Posiadaczom depozytów w bankach spółdzielczych nie przysługuje rzecz jasna wprost roszczenie o zwrot ich depozytów z IPS, lecz nadal z BFG, w trybie wskazanym w ustawie (z 10 czerwca 2016 r. o Bankowym Funduszu Gwarancyjnym, systemie gwarantowania depozytów oraz przymusowej restrukturyzacji). Jednak sama potencjalna pomoc ze strony systemu IPS w postaci pożyczek z funduszu zabezpieczającego IPS jest dodatkowym szczeblem zabezpieczania ich wkładów. 
W pierwszej z nich, gdy funkcjonowaniu banku spółdzielczego, który przystapił do IPS, nic nie zagraża, można wskazywać na wystapienie takich pożytków, jak korzystanie z różnego typu ulg (w zakresie danin na BFG, możliwości stosowania zerowych wag ryzyka itp.), które powoduja poprawę wskaźników płynności czy kapitałów. Wspólny system docelowo ma pozwalać na pozyskanie większej wiedzy o jego członkach, co przekładać się powinno na wzrost zaufania i podniesienie efektywności wykorzystania środków przez banki członków IPS. Korzystne jest także ujednolicenie systemu zarządzania ryzykiem i płynnościa. Nie bez znaczenia jest także wspomniany aspekt marketingowy przynależności do IPS, dzięki któremu banki spółdzielcze mogą wskazać, że objęte są podwójną ochrona ${ }^{42}$.

W sytuacji normalnej, gdy funkcjonowaniu banku spółdzielczego, który przystapił do IPS, nic nie zagraża, można wskazywać na istnienie także pewnych problemów, takich jak: obawa przed utratą niezależności, wydatkowanie nadmiernego wysiłku na eliminowanie ryzyka, którego, jak twierdzą niektórzy uczestnicy debat, tak naprawdę nie ma, a który powinno się przeznaczyć na podnoszenie efektywności działania.

Ważniejsze sa jednak korzyści, które odnoszą banki spółdzielcze należące do IPS, które znalazły się w sytuacji zagrożenia. Po pierwsze, dzięki wspólnemu systemowi zarządzania ryzykiem i płynnością szybko powinny one dostać z systemu informację zwrotna o tym, że mają trudności. Celem systemu jest więc wykrywanie zagrożeń i tym samym skuteczna samokontrola uczestników systemu. Wykrywanie zagrożeń ma być możliwe dzięki ujednoliceniu systemu zarządzania ryzykiem i płynnością w którym będą systematycznie dokonywane całościowe przeglądy ryzyka poszczególnych uczestników IPS oraz systemu jako całości.

W sytuacji zagrożenia kłopotliwe moga być efekty zbyt szybkiego wdrożenia systemu, które odbyło się, jak twierdzą niektórzy cytowani uczestnicy debat, kosztem dopracowania istotnych procedur. Ta ostatnia kwestia, może spowodować problem z uzyskaniem prawidłowej i wysłanej odpowiednio wcześnie informacji zwrotnej z systemu o wystapieniu zagrożeń u uczestnika IPS. To zaś może opóźnić lub zablokować możliwość ich usunięcia na czas.

Bezdyskusyjne są również zalety IPS dla należących do niego banków, które znalazły się w sytuacji kryzysowej. Pomocą w takiej sytuacji będzie fundusz pozwalający na wsparcie banku, który w takiej sytuacji się znalazł. Podkreślić jednak należy, że istnieje duża szansa na to, że dzięki wspólnemu systemowi zarządzania ryzykiem i wiedzy o kondycji pozostałych członków IPS banki spółdzielcze należące do systemu docelowo będą w porę dostawać informacje, dzięki którym uda się uniknąć korzystania z takiego wsparcia.

Jedyną wada, której można doszukiwać się odniesieniu do sytuacji kryzysowej, czyli takiej, gdy konieczna byłaby pomoc finansowa ze strony IPS, jest rozważenie, czy dla relatywnie stabilnych banków spółdzielczych konieczny jest taki dwustopniowy system i czy nie wystarczyłaby sama dotychczasowa ochrona ze strony BFG. Można się zatem zastanawiać, czy (abstrahując od wymogów wynikających z regulacji unijnych) nakład pracy wydatkowany na

${ }^{42} \mathrm{Z}$ uwzględnieniem aspektów opisanych w przyp. 43. 
stworzenie systemu nie mógłby być przeznaczony np. na podniesienie efektywności działania banków.

Podsumowując, należy stwierdzić, że już z samego przeglądu zalet i wad systemu prezentowanego w literaturze i przez praktyków wynika jednoznacznie pozytywna ocena IPS. Jeśli nawet pojawiała się (przed wdrożeniem i w pierwszych miesiącach wdrażania) krytyka pewnych aspektów, to należy podkreślić, iż większość z tych problemów została wyeliminowana.

W ocenie autorki, również po dodaniu jej obserwacji oraz po autorskim usystematyzowaniu i prezentacji w różnych przekrojach zalet i wad systemu IPS, należy wskazać na zdecydowaną przewagę tych pierwszych, a wdrożenie systemu rozpatrywać jako zjawisko pozytywne, zarówno dla samych banków spółdzielczych, jak i jego klientów. Jak wykazano, wdrożenie systemu jest również pozytywne z punktu widzenia banków zrzeszających oraz BFG. Zdaniem autorki także systematyzacja i przegląd korzyści oraz problemów wynikajacych z funkcjonowania IPS w różnych sytuacjach, w jakich mogą się znaleźć banki spółdzielcze, pozwala na sformułowanie wniosków, że zalety sa tu zdecydowanie grupa dominująca, a opisane wady mają charakter przejściowy lub ich znaczenie nie jest ważące.

\section{WNIOSKI I REKOMENDACJE NORMATYWNE}

Warto zauważyć, że prezentowane w literaturze, przytaczane wyżej, wytyczne i rekomendacje skupiają się jedynie na wskazywaniu formy tworzenia zrzeszeń i regulacji sposobu przystępowania do nich. Jak już jednak wspomniano przy ocenie zasadności wdrożenia systemu, większość postulatów prezentowanych w literaturze i przez cytowanych praktyków została już spełniona. Jedynie najbardziej radykalne poglądy, że „przynależność do systemu IPS powinna być obowiązkowa dla każdego banku spółdzielczego należącego do zrzeszenia”, czy „niedopuszczalna powinna być możliwość tworzenia kilku IPS w ramach jednego zrzeszenia oraz przynależność do IPS banku spółdzielczego spoza zrzeszenia" ${ }^{43}$, nie doczekały się realizacji.

Pierwszy postulat trzeba rozpatrywać w kontekście cytowanych wcześniej opinii, według których system, do którego przynależność jest obowiązkowa, rodzi możliwość generowania problemów, które przyczyniły się do fiaska hiszpańskiego modelu IPS. Z drugiej strony jednak warto rozważyć, czy takie rozwiązanie nie byłoby lepsze. Skoro teraz (teoretycznie) takiego obowiązku nie ma (są alternatywy w postaci usamodzielnienia banków, czy stworzenia osobnego zrzeszania dla banków spoza systemu ochrony), ale mimo to większość banków i tak przystapiła do IPS, to rozwiązanie systemowe tej kwestii poprzez narzucenie konieczności przystapienia do IPS przez wszystkie banki spółdzielcze powinno być akceptowalne. Dlaczego jednak miałoby być lepsze? Zdaniem autorki nasilałoby działanie wspomnianego przy zaletach systemu

43 J. Koleśnik, op. cit. 
aspektu „marketingowego”. Dla klientów byłoby bowiem jednoznaczne i czytelne: bank spółdzielczy jest bankiem o podwójnej ochronie (z IPS i BFG). Możliwość wystapienia równolegle różnego stopnia zabezpieczeń choćby w kilku bankach spółdzielczych wprowadza jednak pewną dezorientację klientów osłabiajacca moc działania tego „chwytu marketingowego”.

Drugi z postulatów wiąże się z propozycją przekształcenia zrzeszeń w systemy ochrony. Zdaniem autorki rozwiązanie, jakie aktualnie zostało wprowadzone (czyli spółdzielnia „obok” zrzeszenia), jest korzystniejsze, ponieważ zapewnia wyeliminowanie niepotrzebnych zależności, które mogłyby występować między bankiem zrzeszającym a bankami zrzeszonymi. Forma spółdzielni pozwala na lepsza, bardziej partnerską współpracę całego systemu. Dlatego też założona w Polsce spółdzielnia, a właściwie dwie spółdzielnie, sa dobrym i przemyślanym rozwiązaniem. Można się co prawda spotkać z wzorcami wprowadzania jednego podmiotu sprawujacego rolę systemu ochrony (w Niemczech), jednak w Polsce, przy uwarunkowanym historycznie istnieniu dwóch zrzeszeń, wprowadzenie dwóch odpowiadających im spółdzielni jest rozwiązaniem słusznym, jednakże pod warunkiem, że ich funkcjonowanie będzie maksymalnie ujednolicone.

Należy przy tym jasno wskazać, że IPS jest kolejnym krokiem ku większej integracji. Uzasadnione są więc wspomniane wcześniej przewidywania praktyków co do postępującej utraty niezależności pojedynczych banków spółdzielczych. Niemniej w opinii autorki należy oceniać tę sytuację pozytywnie, ponieważ ujednolicenie systemów, czy wspólne działania marketingowe i „backoffice’owe”, pozwolą na redukcję kosztów i podniesienie efektywności działania i pozycji marketingowej banków spółdzielczych. To właśnie wspólne strategie rozwoju, wspólne działania marketingowe czy szkoleniowe powinny przełożyć się na zwiększenie udziału sektora banków spółdzielczych w rynku, co przy wspomnianej redukcji kosztów powinno podnieść rentowność poszczególnych jego uczestników. Moment rozpoczęcia wdrażania IPS powinien być więc stymulatorem dalszych działań integrujacych banki spółdzielcze.

Przeprowadzona reforma strukturalna, która była pochodna przyjęcia i wdrożenia w UE pakietu CRD IV/CRR, zwiększa wzajemną odpowiedzialność (także finansowa) uczestników systemu, przez co prawdopodobieństwo pojawienia się poważnych problemów u uczestników systemu powinno się zmniejszyć. Problemem jest tu jednak to, że skuteczność systemu będzie zależała od prawidłowości przyjęcia zasad i wdrożenia procedur oceny ryzyka generowanego przez każdego uczestnika systemu. Niestety trzeba też mieć świadomość, że zakres sankcji nakładanych na uczestników systemu jest stosunkowo ograniczony, stąd wysiłki poniesione na rzecz budowy bezpiecznego systemu prewencji muszą być naprawdę duże. Musi w tym zakresie nastapić poważna zmiana jakościowa w porównaniu z dotychczasowymi zasadami działania zrzeszeń.

Zdaniem autorki najważniejsze wytyczne prowadzące do sukcesu IPS sa następujace:

- należy wprowadzić jednolity, przejrzysty, skuteczny system monitorowania ryzyka; 
- trzeba doprowadzić do tego, aby system mógł spełniać funkcje prewencyjne, był systemem wczesnego reagowania, a także miał odpowiednie instrumentarium pozwalające na skuteczne prowadzenie takich działań;

- konieczne jest polepszenie przepływu informacji i upowszechnienie wiedzy o funkcjonowaniu systemu wśród zarządzających i pracowników banków spółdzielczych.

Warto też rozważyć podjęcie konkretnych, skutecznych działań na rzecz zwiększających przejrzystość rachunkowości, sprawozdawczości i audytu, takich choćby, jak cykliczne prowadzenie szkoleń, które faktycznie przekazuja pełną i aktualną wiedzę z tego zakresu. Należy także podjąć dyskusję nad koniecznością wprowadzenia dodatkowej certyfikacji dla biegłych rewidentów specjalizujących się w badaniu banków czy też rozważyć wprowadzenie obligatoryjnego prowadzenia, choćby cząstkowego, audytu wewnętrznego. Są to jednak szerokie zagadnienia, którym warto poświęcić odrębne rozważania.

\section{PODSUMOWANIE}

Reasumując, należy podkreślić, że w obecnym kształcie model IPS wzbudził ogromne, z reguły pozytywne, zainteresowanie zarządzajacych bankami spółdzielczymi działającymi w Polsce. Jednym z dowodów na to jest fakt, że w 2017 r. niewiele jest już takich banków, które do tego systemu jeszcze nie należą. Biorąc dodatkowo pod uwagę, że system ochrony ma, jak wynika z przedstawionej analizy, więcej zalet niż wad, można przypuszczać, że jego wdrożenie przyczyni się do polepszenie funkcjonowania polskiej bankowości spółdzielczej. Tym bardziej że początkowo system ten powstał jako inicjatywa oddolna i funkcjonuje w wielu krajach (choćby w Niemczech już od przeszło 70 lat) z sukcesami do dziś.

Uznać zatem można, że tak naprawdę wprowadzone przepisy unijne (CRR/ CRD IV) nie sa jedynie nowym odgórnie narzuconym pomysłem, ale raczej próbą upowszechnienia dobrych, sprawdzonych wzorców wśród banków spółdzielczych funkcjonujących we wszystkich krajach Unii. Warto także podkreślić, że liczący się praktycy z sektora bankowości spółdzielczej twierdzą że polskie banki spółdzielcze potrzebowały takich zmian i wprowadzenie unijnych regulacji tylko te działania przyspieszyło i pomogło usystematyzować.

Trzeba jednak jednocześnie pamiętać, że wdrażany model IPS działa na razie dzięki dużemu kredytowi zaufania. Dlatego też należy intensyfikować i przyspieszać wysiłki nad rozwiązaniem wspomnianych problemów tak, aby nie zaprzepaścić szansy, jaką jest wdrażanie IPS, które należy traktować jako pierwszy, pozytywny etap nowego kierunku przemian w zakresie funkcjonowania bankowości spółdzielczej w Polsce.

dr Agnieszka Piechocka-Katui̇na

Uniwersytet Ekonomiczny w Poznaniu

agnieszka.piechocka@ue.poznan.pl 


\section{THE ADVANTAGES AND DISADVANTAGES OF THE IPS IN THE COOPERATIVE BANKS SECTOR IN POLAND}

\section{Sum mary}

The aim of this paper was to evaluate the implementation of the Institutional Protection Scheme (IPS) in Poland. First, the idea of the IPSs, their origins and the legal basis underlying their functioning have been presented. Next the IPS model implemented within the Polish cooperative banks sector has been analysed together with a review of the advantages and disadvantages flowing from it. This examination was approached from different points of view, using various criteria. Finally, the author's assessment of the implementation of the IPS model implemented within the Polish cooperative banks sector has been presented, and certain normative conclusions and recommendations formulated. 